\title{
Opportunities and challenges for small-scale aquaculture: The stakeholders' perspective in Los Lagos Region-Chile
}

\author{
Heidi J. Albers ${ }^{1}$, Marjorie Baquedano ${ }^{2,5}$, Carlos Chávez ${ }^{3,5}$, Jorge Dresdner ${ }^{4,5}$, \\ and Kelly Yubini ${ }^{6}$ \\ 'University of Wyoming, Department of Economics. USA. \\ ${ }^{2}$ Universidad de Concepción, Departamento de Educación Médica. Chile. \\ ${ }^{3}$ Universidad de Talca, Facultad de Economía y Negocios. Chile. \\ ${ }^{4}$ Universidad de Concepción, Departamento de Economía. Chile. \\ ${ }^{5}$ Interdisciplinary Center for Aquaculture Research (INCAR), Chile. \\ ${ }^{6}$ Universidad de Concepción, Departamento de Sociología. Chile.
}

\begin{abstract}
H.J. Albers, M. Baquedano, C. Chávez, J. Dresdner, and K. Yubini. 2021. Opportunities and challenges for small-scale aquaculture: The stakeholders' perspective in Los Lagos RegionChile. Int. J. Agric. Nat. Resour. 259-287. We identify and explore the potential opportunities and challenges for promoting and expanding small-scale aquaculture (SSA) as an additional income-generating activity for coastal communities in southern Chile. Based on a conceptual model of SSA adoption decisions, we conducted field key informant semistructured interviews with stakeholders in the Los Lagos region and in the regional capital city, Puerto Montt. We conducted a qualitative analysis of the interviews to identify potential resource users' perceptions of current SSA opportunities. Interpreting the content analysis results through the lens of economic decisions in the conceptual model, we find that weak monitoring and enforcement, difficulties in adapting to new jobs, limited recent spatial planning, constraints on access to marine user rights, and insufficient market development for marine products are among the main obstacles to the adoption of SSA. The stakeholders view SSA as an opportunity to expand marine-based productive activities under the continuous decline in wild fisheries. SSA adoption is perceived as a gradual transition process that requires cultural capital and knowledge, given the lack of familiarity with management and the legal and economic aspects of aquaculture. In contrast to the concerns of potential SSA adopters, government stakeholders emphasize concern over the lack of definitions for SSA, norms, and regulations. We discuss how public policy to promote SSA in Chile could target the key concerns of potential SSA adopters.
\end{abstract}

Keywords: Fisheries, income generating activities, qualitative analysis, small-scale aquaculture.

\footnotetext{
${ }^{1}$ Aquaculture production represents approximately $46 \%$ of global fish production, $55 \%$ of crustacean production, and $73 \%$ of mollusk production (FAO, 2018 and 2017).
} 


\section{Introduction}

The aquaculture sector has experienced a rapid increase in production at the global level in recent decades, contributing to food security, employment, and new income opportunities in several regions of the world (Garlock et al., 2020). ${ }^{1}$ Although most aquaculture production occurs in industrial sectors, small-scale aquaculture (SSA) is seen as an opportunity to provide alternative livelihood options for local communities in developing and transitional countries (Salazar et al., 2017; Kaliba et al., 2007; E-Jahan et al., 2010; Ahmed \& Lorica, 2002). These opportunities could be especially relevant in countries with highly productive coastal areas facing the negative impacts of declining fishing activities. ${ }^{2}$

One example is coastal communities in Chile, which have traditionally depended on wild fish resources but where depletion of stocks implies a need to reduce fishing efforts. With most of the main fisheries either overexploited or collapsed (Subsecretaría de Pesca y Acuicultura, 2019a), the Chilean government has proposed SSA as a means to generate new income opportunities (Subsecretaría de Pesca y Acuicultura, 2019b, CORFO 2016). ${ }^{3}$ Thus far, government programs to promote SSA to diversify the production alternatives for coastal communities and artisanal fishers have focused mainly on the financial and technical aspects and on defining a specific set of rules/norms for its operation, without specific consideration of the willingness to adopt SSA or the obstacles, challenges, and opportunities to that adoption from the perspective of stakeholders. ${ }^{4}$
Although SSA offers new opportunities to improve welfare in coastal areas, the transition from capture fisheries and other traditional activities to SSA may face several obstacles and challenges. In this paper, we identify and explore the potential opportunities and challenges for promoting and increasing small-scale aquaculture (SSA) as an additional income-generating activity for coastal communities in southern Chile based on the views of stakeholders. We conducted field key informant semistructured interviews with artisanal fishers, leaders of fishers' unions, and government officials to learn their views on the potential for SSA activities in different fishing villages of Los Lagos region, in the regional capital city of Puerto Montt, and in Valparaiso. We met with regional and central government officials from the National Fisheries Service, Technical Service of Cooperation, and the Undersecretary of Fisheries and Aquaculture. We conducted a qualitative analysis of the interviews and then interpreted those results through the lens of a conceptual model of SSA adoption decisions. We use that analysis and interpretation to inform our discussion of SSA policy considerations.

The paper is organized as follows. In Section 2, we describe the regulatory setting for SSA in Chile and the case study setting of the Los Lagos region in southern Chile, detail how we collected information through semistructured interviews, and identify the stakeholder groups interviewed. Section 3 includes a conceptual framework for our analysis, a description of interviews and participants, and a description of qualitative methods for interview data analysis. Section 4 presents

\footnotetext{
${ }^{2}$ Although there is not a unique definition, the SSA refers to farming aquatic organisms, including fish, mollusks, crustaceans and aquatic plants by individuals, legal entities, or local communities. The activities are performed with low level of investments, and cultivation is mostly extensive, making the production process dependent on capturing food from the natural environment.

${ }^{3}$ Considering the 27 fisheries reported as having Scientific Fisheries Councils' evaluations of its status by 2018, 19 of them were either overexploited or collapsed, while the remaining 8 were declared as fully exploited (Subsecretaría de Pesca y Acuicultura, 2019).

${ }^{4}$ In practice, most government efforts to promote SSA thus far have entailed providing funding support for projects targeting artisanal fishers' organizations holding territorial use fights for fisheries (TURFs).
} 
the results of the qualitative analysis. We identify key producer characteristics associated with SSA engagement and present results regarding the different restrictions that private stakeholders encounter and that can limit the development of SSA. Based on the results, in Section 5, we discuss how public policy to promote SSA in Chile could address the concerns and restrictions encountered by potential SSA adopters. Finally, in Section 6, we conclude.

\section{SSA policy and Los Lagos case study setting}

In this section, we summarize the special regulatory setting for SSA in Chile; present the location selected for the study, the Los Lagos region; and discuss the reasons why this region is especially interesting for the purposes of this study. Finally, we describe how we collected data through semistructured interviews, and we identify the stakeholder groups interviewed.

\section{Chilean Regulatory Setting}

The Chilean Aquaculture National Policy, enacted in 2003, recognized that SSA should be treated differently from industrial aquaculture in ways that improve small producers' access to the activity (PNA, 2003). One basic issue was to define which activities were to be considered SSA and that therefore should enjoy this differentiated treatment. ${ }^{5}$ In November 2019, the Undersecretary of Fisheries and Aquaculture (Subsecretaría de Pesca y Acuicultura, SUBPESCA by its Spanish acronym) proposed a regulation specific to SSA. ${ }^{6}$ This proposal identifies the type of sites where SSA can be developed: aquaculture concessions, artisanal fishing coves (caletas), benthic resource management and exploitation areas (BRMAs; hereafter, we refer to them as territorial user rights in fisheries, TURFs by its English acronym), indigenous people's coastal marine territories (Espacio Marino Costeros de los Pueblos Originarios, EMCPOs by its Spanish acronym), and private lands. ${ }^{7}$ Moreover, the proposal defines SSA open site projects as monocultures of macroalgae, mussels, or scallops and polycultures incorporating other species, such as native fish species and urchins. The aquaculture of exotic species is explicitly forbidden, which excludes salmon production from this regulation. Finally, the definition of the proposed SSA establishes the following quantitative standards:

- When the producer is an individual or a legal entity with aquaculture projects that have only the allowed species, a total area of less than 10 ha and a maximum annual production of less than 500 tons, they will be considered small-scale aquaculture producers.

- Artisanal organizations, cooperatives and indigenous communities are considered small-scale aquaculture producers when they produce the allowed species, occupy less than 50 ha and have a maximum annual production of less than 2000 tons.

These SUBPESCA definition of SSA raise several issues. First, the criteria used do not include socioeconomic aspects of the producers despite the fundamental purpose of defining SSA being to provide opportunities for small producers with limited credit access (PNA, 2003). Second, the quantitative standards for

\footnotetext{
${ }^{5}$ The knowledge that the SUBPESCA had of SSA at that time was scarce. Thus, it funded several research projects over the years that allowed for characterizing and identifying criteria to define the SSA sector from different perspectives: socioeconomic, environmental, sanitary, technological, and site locational (FIPA 2004-26, FIPA 2005-15, FIPA 2007-48, FIPA 201502, FIPA 2017-16).

${ }^{6}$ In November 2019, a new law (Law 21,183) that allows relocating aquaculture concessions for SSA and provides more juridical certainty for mussel seed collectors was enacted. This law was not known when the interviews were conducted.

${ }^{7}$ Open stock companies are explicitly excluded from the private producers that can have small scale aquaculture concessions on private lands.
} 
area and production do not differentiate by resource type or the location of production (Subsecretaría de Pesca y Acuicultura, 2019b). Third, the proposed regulation may not reflect how stakeholders view SSA, which is the motivation for the analysis presented here.

\section{Case Study Setting: Los Lagos Region Characteristics}

Chile has a highly productive marine ecosystem along its long coastline. Most SSA is, however, concentrated in specific regions. Our study is located in the Los Lagos region, which is the most important region involved in SSA by volume, value, and population (FIPA 2004-26). It is located in the southern part of the country (between $40^{\circ} 13^{\prime}$ and $44^{\circ} 3^{\prime}$ south latitude and $74^{\circ} 49^{\prime}$ to $71^{\circ} 34^{\prime}$ west longitude). This region is characterized by its marine resource productivity and biogeographic diversity. The economic structure is composed of many nature-based activities, such as agriculture, livestock farming, forestry, seafood extraction and aquaculture. The principal species identified in SSA are mussels (Mytilus chilensis) and "pelillo" seaweed (Agarophyton chilensis), which together comprise $96 \%$ of all aquaculture farms in the sector (Salazar et al., 2018). The region presents varied natural biogeographic conditions for diverse marine-based activities (zones exposed to open sea conditions, sheltered coves, inner sea protected areas, estuaries, access to markets).

\section{Approach, Methodology, and Data}

Policies to expand SSA rely on the response of households to opportunities for SSA. To elucidate the range of potential responses to such opportunities, we develop a conceptual framework of SSA activity adoption and use it to interpret the results of a qualitative analysis of stakeholder interview discussions. Here, we describe that framework, the interview data, and the qualitative data analysis that we employ.

\section{Conceptual Framework}

We base a conceptual framework of how individuals make decisions about adopting smallscale aquaculture on the economics and policy literature of agricultural technology adoption and aquaculture adoption in other settings (e.g., Slater et al. 2013; Pierpaoli et al., 2013; Diedrich et al., 2019). Individuals aim to maximize their expected utility, subject to various constraints, by choosing whether to engage in small-scale aquaculture and, if so, choosing the type and amount of time allocated to SSA. The expected utility of adopting a new activity is a function of its additional income, the variability of that income, and the individual's preferences across particular activities beyond profitability. The constraints on their decisions include their current situation, the availability of time and capital, their information set, and their opportunity set.

Translating the general expected utility maximization framework to the Chilean small-scale aquaculture setting requires several steps. First, in Chile, some types of SSA can only be pursued by cooperatives and/or can only be pursued with particular user rights, which means that an individual's starting point for deciding to adopt or expand SSA depends on their membership in cooperatives and their holding of marine user rights. Second, the household's geographic location contributes to both the types of SSA activities available and their relative profitability in their opportunity set. Similarly, the degree of compatibility of different SSA activities with other household production decisions can affect households' decision to expand their activities to include SSA. Third, as with many new production opportunities, households may not have information specific to their situation regarding the various activities' production processes or the various outputs' market processes, with both factors determining the profitability of adopting SSA. Fourth, the institutional and current (spatial) use and rights setting also informs the expected profitability of different SSA actions. For example, 
pollution, including spillovers from salmon farming, could potentially alter the profitability of nearby SSA activities. In another example, the profitability of activities could be limited by illegal harvesting in the absence of institutions and actions to enforce marine property rights.

This conceptual model of households making expected utility-maximizing decisions about adopting small-scale aquaculture suggests that households will adopt SSA when they expect higher profits from SSA activities than from other uses of their human, physical, and natural capital but that they also consider income variability and nonmonetary aspects of these activities, such as cultural norms. In addition, forming expectations of profitability requires information specific to their situation. Although this framework provides some general guidance for understanding households' SSA adoption decisions, policy guidance requires more specific information.

\section{Interviews and participants}

To provide more specific insight into potential responses to SSA opportunities and based on this conceptual framework, we conducted semistructured interviews to elicit stakeholders' preferences across activities, their perceptions and information sets for the processes and profitability of different activities, their information sets, and their perceptions of potential obstacles and opportunities to SSA adoption (Albers et al., 2021).

The productive and biogeographic diversity found in this region generates a wide range and variety of income-generating activities, socioeconomic living conditions, and stakeholder perceptions (Albers et al., 2021). This diversity led us to select field interview sites across a range of communities, with particular emphasis on capturing many types of potential SSA producers in many types of locations. A preliminary analysis of the distribution of activities in the Los Lagos region showed that each zone supports diverse marine activities and that people undertake many different SSA activities. However, the set activities differ across zones, depending on the biogeographical characteristics of the territory. We identified four main zones in the northern part of the Los Lagos region: zone 1, located in the Gulf of Ancud; zone 2, located in Puerto Montt Bay; zone 3, located in the Cochamó district in the Reloncaví Estuary; and zone 4, located in the Hualaihué district (see Table 1 and Figure 1). The different biogeographical characteristics determine the degree to which different marine economic activities are pursued; for example,

Table 1: Productive characteristics of the different zones, 2016 (percentages of total)

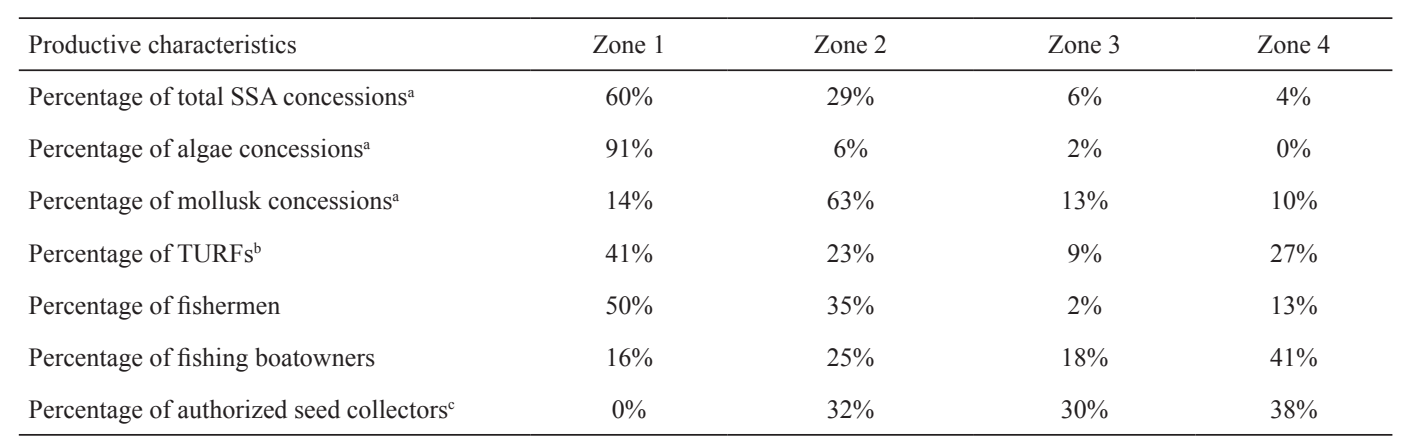

Sources: Subsecretaría de Pesca y Acuicultura, Chile and Directemar (Maritime authority) Notes:

ancludes all SSA concessions (mussel and algae) registering harvest in the period 2014-2018.

${ }^{b}$ Includes all TURFs granted.

"The number of seed collectors includes collectors authorized in Turfs and Transitory Special Permits ("Permisos de Escasa Importancia"). 


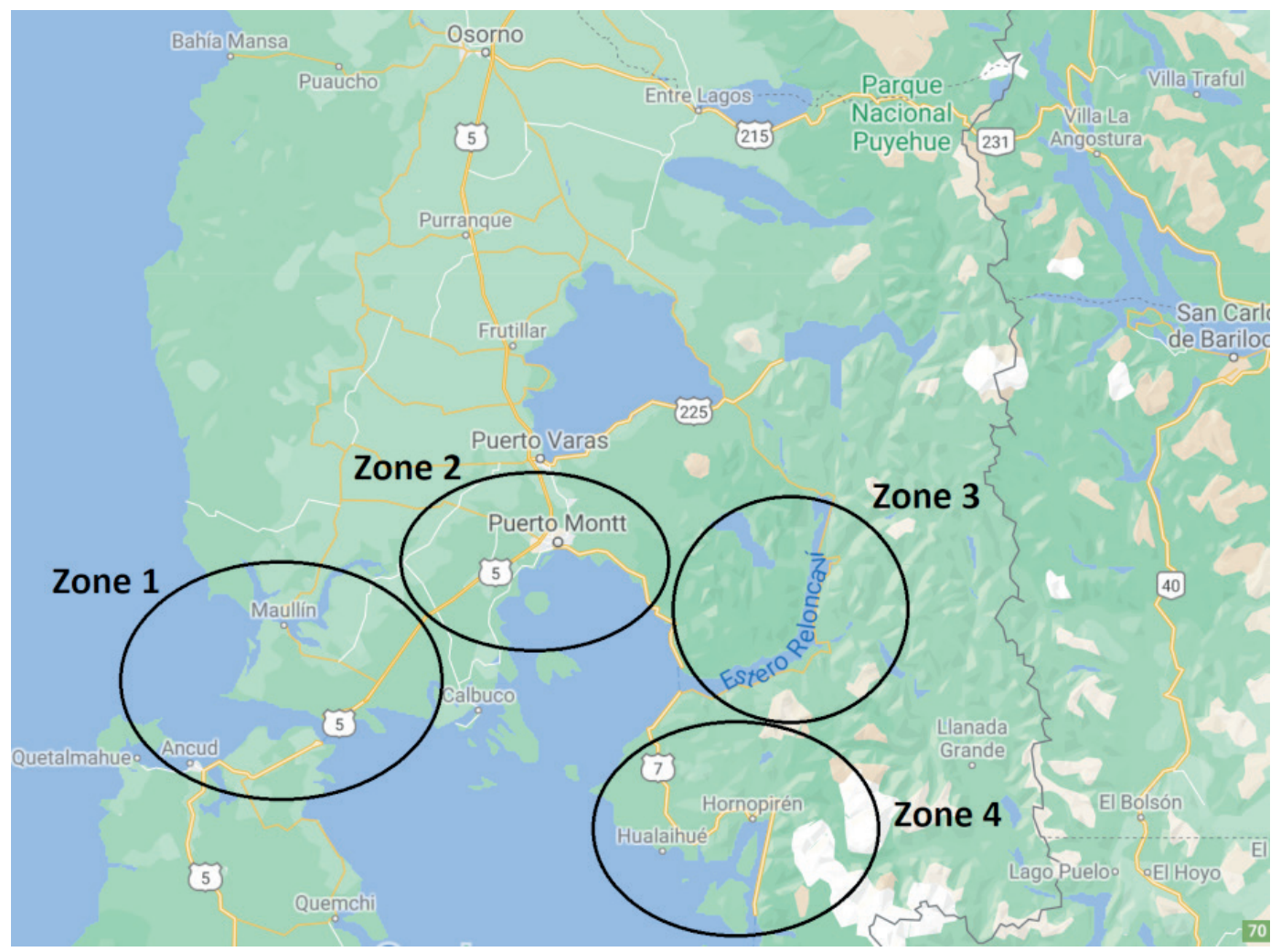

Figure 1. Biogeographical Zones in Los Lagos Region

algae concessions, TURFs, and shore fishermen are concentrated in zone 1 , while mussel concessions are prevalent in zone 2 . In contrast, mussel seed collectors were concentrated in zones 3 and 4 (Table 1). Finally, the pelagic fishing fleet is concentrated in zone 4 , while zone 3 is characterized by estuary conditions.

In selecting interviewees, we covered these zones to ensure that we captured the diversity of productive activities and life conditions met by the stakeholders. The stakeholders interviewed were leaders of artisanal fishers' organizations, organizational leaders from fisher villages, government officials working in fisheries and aquaculture regulatory agencies, artisanal fishers, and members of coastal communities who perform marine economic activities (i.e., fishers, seafood collectors, and small-scale aquaculture farmers). We also interviewed local government officials from the capital city of the region, Puerto Montt, and from the Servicio Nacional de Pesca y Acuicultura and the Subsecretaría de Pesca y Acuicultura in Valparaiso.

We selected participants using an intentional sample of people pursuing small-scale marine resource productive activities; people working both within organizations and on an individual level, and governmental entities; and we included males and females. As is typical in qualitative research, the sample was determined during the data collection process following a complementary "snowball" strategy in which one participant leads to another participant in a manner that ensures heterogeneity (Aspers \& Corte, 2019: Teddlie \& Yu, 2007; Flick, 2006). The final sample included 29 participants who captured regional heterogeneity in the different types of stakeholders who participated or might participate in the future in small-scale aquaculture. 
As planned in the intentional participant selection process, these stakeholders vary across producer types, organizational membership versus individual producers, extracting versus farming seafood (not farming), TURF participation, and both TURF and aquaculture farming. Although all categories contain women, we analyze a union with a concession for algae collection that is comprised of only female members as a separate category. In addition, we consider all government employee interviews as a separate category. The interviews were recorded and transcribed for qualitative analysis. ${ }^{8}$ In Table 2 , the number of interviews and participants, main targeted species, and working zones by stakeholder category are presented.

\section{Data}

To collect the interview data, we conducted face-to-face individual or group semistructured interviews, depending on the stakeholders' preferences. This technique offers the opportunity to ask a set of questions covering transversal key themes but also provides flexibility to explore emergent topics during the data collection process (Patton, 2002; Flick, 2006). All stakeholders were asked about two main topics: a) small-scale aquaculture activities and b) enforcement and compliance. A third topic exploring marine activities was asked to all participants except for central and regional

Table 2. Number of interviews and participants by stakeholder categories, zones and main targeted species/activity

\begin{tabular}{|c|c|c|c|c|c|}
\hline $\begin{array}{l}\text { Stakeholder Category } \\
\text { (Code) }\end{array}$ & Code & ID & $\begin{array}{c}\mathrm{N}^{\circ} \text { of } \\
\text { participants }\end{array}$ & $\begin{array}{l}\text { Zone (specific } \\
\text { location) }\end{array}$ & Main targeted Species/activity \\
\hline \multirow[t]{4}{*}{$\begin{array}{l}\text { Organization with TURF } \\
\text { only extractive }\end{array}$} & \multirow[t]{4}{*}{$\begin{array}{l}\text { Org-Turf- } \\
\text { Extr }\end{array}$} & Interview 1 & 1 & 1 (Carelmapu) & $\begin{array}{l}\text { Loco (wild abalone), sea } \\
\text { urchin, red sea squirt, barnacles }\end{array}$ \\
\hline & & Interview 2 & 1 & 1 (Maullín) & $\begin{array}{c}\text { Loco (wild abalone), sea } \\
\text { urchin, red sea squirt, barnacles }\end{array}$ \\
\hline & & Interview 5 & 1 & 1 (Ancud) & Clam, algae (gracilaria), \\
\hline & & Interview 15 & 3 & 4 (Quildaco) & Algae, clam \\
\hline \multirow{2}{*}{$\begin{array}{l}\text { Organization without } \\
\text { TURF only extractive }\end{array}$} & \multirow[t]{2}{*}{ Org-Extr } & Interview 12 & 1 & 4 (Hornopirén) & Conger, Austral hake, mussels \\
\hline & & Interview 14 & 2 & 4 (Hualaihué) & $\begin{array}{l}\text { Hake, razor clams, algae, } \\
\text { clams }\end{array}$ \\
\hline \multirow{5}{*}{$\begin{array}{l}\text { Organization with TURF } \\
\text { and SSA }\end{array}$} & \multirow{5}{*}{$\begin{array}{l}\text { Org-Turf- } \\
\text { SSA }\end{array}$} & Interview 9 & 2 & 3 (Cochamó) & Mitilids, sea bass \\
\hline & & Interview 3 & 2 & 1 (Estaquilla) & Loco (wild abalone), algae \\
\hline & & Interview 10 & 1 & 3 (Cochamó) & Mussel seed collector \\
\hline & & Interview 13 & 1 & 4 (Hornopirén) & Mitilids, algae \\
\hline & & Interview 16 & 1 & 3 (La Arena) & $\begin{array}{l}\text { Conger, sawfish mackerel, } \\
\text { mitilids }\end{array}$ \\
\hline \multirow[t]{4}{*}{ Government } & \multirow[t]{4}{*}{ Gov } & Interview 7 & 1 & 2 (Puerto Montt) & Not applicable \\
\hline & & Interview 8 & 1 & 2 (Puerto Montt) & Not applicable \\
\hline & & Interview 17 & 4 & $\begin{array}{l}\text { No zone } \\
\text { (Vaparaíso) }\end{array}$ & Not applicable \\
\hline & & Interview 18 & 3 & $\begin{array}{l}\text { No zone } \\
\text { (Vaparaíso) }\end{array}$ & Not applicable \\
\hline $\begin{array}{l}\text { Women only organization } \\
\text { (marine concession holder) }\end{array}$ & Org-women & Interview 6 & 1 & $\begin{array}{l}4 \text { (Contao- } \\
\text { Hualaihué) }\end{array}$ & Algae (Gracilaria) \\
\hline \multirow[t]{2}{*}{ Aquaculture farmers } & \multirow{2}{*}{$\begin{array}{l}\text { Aqua- } \\
\text { farmers }\end{array}$} & Interview 11 & 1 & 4 (Pichicolo) & Mitilids \\
\hline & & Interview 4 & 2 & 1 (Ancud) & Oysters, algae \\
\hline Total & & 18 & 29 & & \\
\hline
\end{tabular}

\footnotetext{
${ }^{8}$ In addition, the interviews were used to define a survey instrument that generated data for quantitative analysis (Albers et al., 2021).
} 
Table 3. Themes covered in the semistructured interview by stakeholders

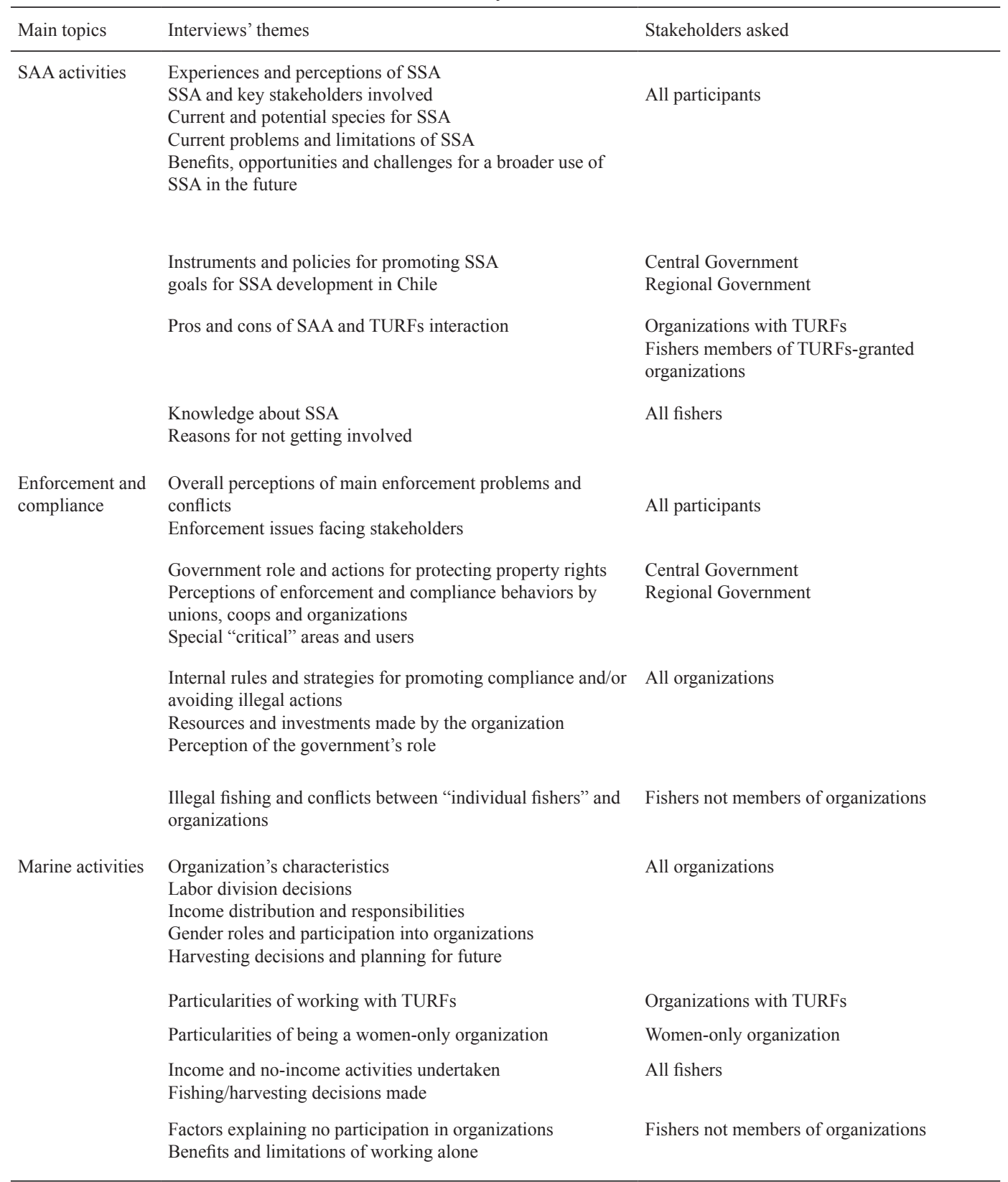

government stakeholders (see Table 3 and the Appendix for the semistructured interview questionnaire by stakeholder category). All interviews were performed in person by a team of three researchers and a field work coordinator during April 2018.

\section{Qualitative Methods for Interview Data Analysis}

The overall qualitative approach was to analyze the interview text according to the grounded theory approach, which codes participants' discourse into common key themes and identifies differences 
across relevant stakeholder categories (Glasser \& Strauss, 2017; Strauss \& Corbin, 1997). This section details the participants' characteristics, data collection process, sample settings, instruments and stages of qualitative analysis applied.

Our data analysis is based on 125,538 words, which correspond to a total of 247 pages transcribed. We conducted the three analytical phases proposed by the constant comparison method (MCC) supported by grounded theory: open, axial, and selective coding. Open coding classifies the information contained in the transcripts into categories, whereas axial coding associates those categories to give them a logical organization and sequence. Finally, selective coding summarizes categories to obtain a more interpretative framework of the opportunities and challenges of SSA (Glasser \& Strauss, 2017). All data processing and analysis were conducted using NVivo (QSR International Pty Ltd, Melbourne Australia).

First, we proceeded with an open coding phase in which the information contained in the tran- scripts was classified into specific categories. Two researchers separately read, wrote notes, and open-coded the transcripts of each of the 18 interviews. The output included a total of 36 open codes. Then, we addressed an axial coding phase grouping all these codes in a logical sequence, which is typically known as a "codebook" in qualitative research. To do so, both researchers reached an agreement about what codes to omit and what codes to include in the codebook. Table 4 shows the codebook composed of a set of six main categories and specific codes or subcategories for each category.

In the selective coding phase, we first performed a simple quantitative analysis accounting for the number of stakeholders who effectively reported information about the six main categories and their subcategories. The rationale behind such analysis was ensuring that the results presented here were based on substantive evidence because not all interviews asked about all six categories and subcategories. Most questions related to subcategories included in "transition from fishing

Table 4. First codebook as output of the axial coding phase

\begin{tabular}{ll}
\hline Category & Subcategories \\
\hline & $(1.1)$ definition of SSA \\
(1) "lack of regulation for SSA" & $(1.2)$ monitoring and enforcement \\
& $(1.3)$ barriers for law compliance \\
& $(2.1)$ beginning/organization background \\
& $(2.2)$ species management \\
(2) "transition from fishing to aquaculture and other & $(2.3)$ SSA opportunities \\
activities" & $(2.4)$ motivation for transition \\
& $(2.5)$ complementary labor activities \\
& $(3.1)$ TURFs space opportunities for SSA \\
& $(3.2)$ cooperation and associativity \\
& $(3.3)$ space conflicts \\
(3) "spatial planning and interaction" & $(3.4)$ access to marine resources rights settings \\
& $(3.5)$ biogeographical settings \\
& $(3.6)$ socioeconomic settings \\
(4) "access and development of markets" & $(4.1)$ commercialization \\
& $(4.2)$ limitations for access markets \\
(5) "governance and institutional support" & $(5.1)$ support agencies \\
& $(5.2)$ government evaluation \\
(6) "sociocultural aspects: gender, age, and ethnicity" & (6.1) gender issues \\
& $(6.2)$ ethnicity \\
& $(6.3)$ cultural \\
\hline
\end{tabular}


Table 5. Number of quotations by stakeholder category across themes

\begin{tabular}{lccccc}
\hline & Organization & Organization & & & Women \\
Categories and & with & without & Organization \\
subcategories & $\begin{array}{c}\text { TURF only } \\
\text { extractive }\end{array}$ & $\begin{array}{c}\text { TURF only } \\
\text { extractive }\end{array}$ & $\begin{array}{c}\text { with TUR } \\
\text { and SSA }\end{array}$ & $\begin{array}{c}\text { Government } \\
\text { organization } \\
\text { (marine } \\
\text { concession) }\end{array}$ & $\begin{array}{c}\text { Aquaculture } \\
\text { farmers }\end{array}$ \\
\hline
\end{tabular}

1. Lack of regulation for SSA

1.1 Definition of SSA

1.2 Monitoring and enforcement

1.3 Barriers for law compliance

2. Transition from fishing to aquaculture and other activities

\subsection{Beginning/}

organization

background

2.2 Species

management

2.3 SSA opportunities

2.4 Motivation for transition

2.5 Complementary labor activities

3. Spatial planning and interaction

3.1 TURFs space opportunities for SSA 3.2 Cooperation and associativity

3.3 Space conflicts

3.4 Access to marine resources rights settings

3.5 Biogeographical settings

3.6 Socioeconomic settings

0

0

0
0

4

4

2

0

0

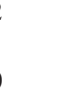

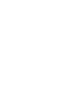

$\begin{array}{lllll}1 & 4 & 0 & 0 & 5 \\ 5 & 2 & 1 & 2 & 12 \\ 3 & 2 & 0 & 0 & 5\end{array}$

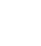


to aquaculture and other activities" and "spatial planning and interaction" (themes 2 and 3 ) were addressed with most interviewed stakeholders (Table 5). However, the questions related to "lack of regulation for SSA" (theme 1) were mainly addressed by interviews with the government, as observed in the subcategories "definition of SSA" (1.1) and "barriers to noncompliance" (1.3). A similar pattern appears in some of the subcategories belonging to "access and development of markets", "governance and institutional support", and "sociocultural aspects: gender, age, and ethnicity" (themes (4), (5), and (6), respectively). The general picture that emerges is that some categories were covered only with some of the interviewed stakeholders; therefore, we explicitly consider the specific stakeholders expressing opinions when we present and discuss the results.
Finally, and after observing the quantity of information available by stakeholders, a new codebook was discussed by the entire research team. We checked the coding accuracy and reached the final grouping of data composed of two main categories: (1) producer characteristics that are associated with the use of SSA, which regrouped information from the initial axial categories "transitions from fishing to aquaculture and other activities" and "sociocultural aspects, gender, age and ethnicity" (see Table 4), and (2) constraints on engaging in SSA, which reclassified the categories "lack of regulation for SSA", "spatial planning and interaction", "access and development of markets" and "governance and institutional support".

Figure 2 shows the final structure of categories and subcategories obtained from a selective analytical phase.

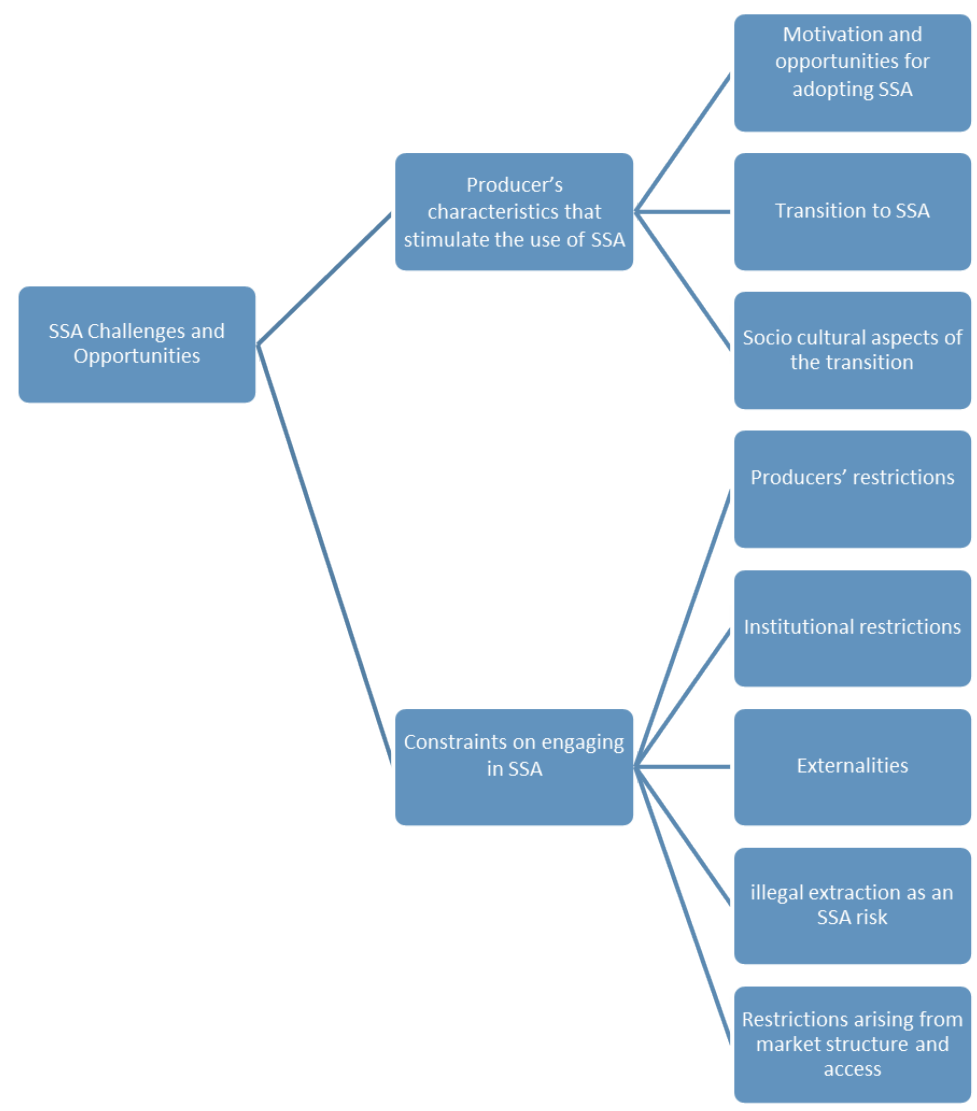

Figure 2. Final codebook of categories and subcategories across stakeholders 
The data grouping that we show in Figure 2 is the guideline for presenting the results in the next section.

\section{Results}

In this section, we present the results of our qualitative analysis as follows. First, we identify key characteristics of producers that are associated with the use of SSA. Second, we present results regarding the different restrictions that private stakeholders encounter and that can limit the development of SSA. We distinguish limitations that potential producers show in SSA development, institutional restrictions, risks associated with an activity, and structural restrictions of an activity. ${ }^{9}$

Producers' characteristics that promote the use of SSA

\section{Motivation for adopting SSA}

The principal motivation for stakeholders to adopt SSA seems to be the perception that marine resources have become scarce and that they provide less return than other uses of their labor time. Compared to traditional marine resource extraction, members from organizations allocate efforts to other activities that are more profitable [OrgTurf-Ext-Interview 1 and Org-women-Interview 6] or less scarce [Org-Turf-Ext-Interview 5 and Org-Turf-SSA-Interview 13]. These activities include small-scale aquaculture as well as other activities, such as employment in large-scale aquaculture in salmon farms, small businesses/ commerce, and tourist activities. Nevertheless, the perception of profitability is constrained by a lack of familiarity with the management, legal, and economic aspects of aquaculture production [Aqua-farmer Interview 11].

\section{Transition to SSA}

Although stakeholders report a positive perception of engaging in SSA, it is seen as an additional but complementary activity to several other activities that households pursue throughout the year [OrgTurf-Extr-Interview 1, Org-Turf-Extr-Interview 5, Org-women-Interview 6, Org-Turf-SSA-Interview 13]. In this sense, it does not completely replace other activities. The transition to SSA is considered an private decision [Gov-Interview 8]. Moreover, it happens gradually. Some aquaculture farmers report that they have been transitioning from fisheries to SSA for 12-15 years. They have gradually expanded the cultured area and incorporated more family labor in the enterprise but have maintained some fishing activity [Aqua-farmers-Interview 11]. Nevertheless, some stakeholders report that at the organization level, it might be difficult to engage in SSA when not all members agree or are willing to participate [Org-Turf-Extr-Interview 2]. Only approximately one-third of the mussel farmers in 2018 (1,133 concessions) were producers registered in the record of artisanal fishers [Gov-Interview 8], which implies that most of these producers transitioned to SSA from nonfishing sectors.

\section{$\underline{\text { Sociocultural aspects of adopting SSA }}$}

The sociodemographic characteristics of the local population, including gender, age, and fishing culture, influence perceptions about transitioning to SSA and the types of SSA pursued. First, few women engage in fishing itself, although many are involved in the marketing of fish [Org-women-Interview 6] due to the physical nature of fishing work [Org-Turf-SSA Interview 16] and cultural resistance to women fishers. Instead of fishing, women are more involved in the onshore collection activities of resources and in small-scale aquaculture activities as income-generating activities [Org-

\footnotetext{
${ }_{9}$ Due to space limitations, we placed the main quotations from stakeholders' interviews in an online appendix, which is available at:https://docs.google.com/document/d/11vs2XwDEOKoF6nvCMWFQT1W6o0B9WHHW/edit?usp=sharing.
} 
Extr-Interview 14, Org-Turf-Extr-Interview 15, Org-women-Interview 6]. In addition, SSA activities allow women to have flexibility in allocating their household labor across income generation activities in combinations that work well for them [Org-Turf -SSA-Interview 16].

Second, younger people appear more open to exploring and trying new activities [Org-Turf-ExtrInterview 5, Org-Extr-Interview 14], potentially including small-scale aquaculture; however, these people are also more willing to migrate out of the coastal zones for education or other work. Currently, there is the perception of increasing participation of the younger generation in aquaculture activity with a "business view" [Org-Turf-SSA-Interview 10]. Some interviews also report improvements in organizations' management because of more educated and younger participants [Org-TurfSSA-Interview 10]. In contrast, older people have more resistance to changes in labor and lifestyle [Org-Turf -SSA-Interview 13], making older fishermen less likely to transition from fishing to SSA [Gov-Interview 18]. Similarly, fishers whose tradition of marine resource-based activities establishes their "fishers' identity" may discourage a transition to SSA [Org-Turf-Extr-Interview 5, Org-Turf-SSA-Interview 3].

Third, among broader regional resource conflicts, interviews report conflicts regarding the allocation of space for marine use rights, including positive discrimination for indigenous coastal groups [Org-Turf-Extr-Interview 5, Gov-Interview 18].

\section{Constraints on Engaging in SSA}

Stakeholders identify a number of constraints and risks that influence their decisions to engage in SSA.

\section{Producers' restrictions}

Potential and current SSA producers agree that funding is a central constraint on expanding
SSA [Org-Turf-Extr-Interview 2, Org-TurfExtr-Interview 5, Org-Turf-Extr-Interview 15, Org-Extr-Interview 14, Org-Turf-SSA-Interview 9, Gov-Interview 18, Gov-Interview 7, Org-womenInterview 6, Aqua-farmers-Interview 11]. Other perceived constraints are specific to the type of stakeholder. Stakeholders with no legal rights to areas identify "space" as a basic constraint [OrgTurf-Extr-Interview 1, Org-Turf-Extr-Interview 2, Org-Turf-Extr-Interview 5, Org-women-Interview 6]. Organizations that have access to space but do not use that space for SSA indicate that the biogeographic conditions constrain the implementation of SSA. In contrast, organizations that engage in SSA view technology, knowledge, training, and assistance as constraints [Org-TurfSSA-Interview 3, Aqua-farmers-Interview 4, Org-Turf-SSA-Interview 16].

Nongovernment stakeholders agree on the need for expert assistance for the transfer of knowledge and technical training [Org-Turf-Extr-Interview 5, Org-Turf-Extr-Interview 2, Org-Extr-Interview 14, Org-Turf-Extr-Interview 15, Org-women-Interview 6]. Although there are specific programs already executed, the interviews report that existing programs focus mostly on subsidies for equipment and pilot projects [Gov-Interview 8, Org-TurfSSA-Interview 9]. Nevertheless, the possibility of networks and the transfer of knowledge from other organizations with previous experience in SSA can help not only regarding what to do but also what to avoid [Org-Turf-SSA-Interview 9]. Some interviews indicate that technical assistance work from consulting firms should be monitored by public agencies and that the government should consider longer timeframes for conducting pilot studies [Org-Turf-SSA-Interview 16]. Government stakeholders describe active participation in extension activities and programs but also identify that the local populations appear to lack knowledge of the extension and advisory services available [Gov-Interview 17].

Stakeholders suggest that limited knowledge about SSA production-especially about what species/ 
products will be profitable within their own biogeographic zone-presents a significant obstacle to expanding these activities. Stakeholders report uncertainty about which, if any, species will be productive in their local area [Org-Turf-SSA-Interview 16, Aqua-farmers-Interview 11, Gov-Interview 18] and about conflicts between productive processes [Org-Turf-Extr-Interview 1, Gov-Interview 7, OrgTurf-SSA-Interview 13]. Nevertheless, they express interest in diversifying activities and making fuller use of their areas [Org-Turf-SSA-Interview 10]. In addition, stakeholders report that payments for patents and environmental reports to begin new activities within existing TURFs are prohibitively expensive [Org-women- Interview 11].

\section{$\underline{\text { Institutional restrictions }}$}

The institutional setting and past policy decisions introduce further restrictions for potential SSA producers.

Government stakeholders describe issues with the current regulatory setting for SSA that limit its expansion. The current law overseeing aquaculture, the General Law of Fishing and Aquaculture (GLFA, 2019), sets industry standards for environmental, pest, and sanitary regulations that small-scale farmers struggle to meet, which constrains their ability to access markets and patents [Gov-Interview 17]. In addition, the lack of formal legal structure for SSA, as opposed to larger aquaculture production, implies that potential SSA farmers have limited access to formal credit sources [Gov-Interview 18]. Government stakeholders argue that the definition of SSA and its regulation should take an ecosystem approach [Gov-Interview 7] that reflects the size of the area and the volume of production and that varies across species, e.g., algae and mussels. Moreover, the new regulation should simplify and promote the development of polycultures instead of the current approach, which encourages SSA that relies on a single crop [Gov-Interview 18]. Government stakeholders stress that the number of species that can be cultured is low, that SSA must be based on cheap technology or low investment levels and that multispecies management offers better opportunities for an economically sustainable form of SSA [Gov-Interview18].

Current uses of seascape space reflect both previous government allocation of rights and individual and group decisions about activities pursued in particular locations, with the space for farming species limited by biogeographic conditions [Gov-Interview 7]. Individuals and organizations describe their spatial choices based on the suitability and profitability of a particular area for a specific marine resource activity, although finding suitable locations and obtaining rights to those locations can be a challenge [Org-TurfExtr-Interview 2]. Nevertheless, organizations suggest that their location decisions reflect what activities will be productive in particular conditions, considering water depth [Org-TurfSSA-Interview 9, Org-Turf-SSA-Interview 13], currents [Org-Turf-SSA-Interview 13], the types of naturally occurring species in a location [OrgExtr-Interview 14, Org-Turf-SSA-Interview 9, OrgTurf-SSA-Interview 10], and nearby contamination [Org-Turf-SSA-Interview 9]. Some nongovernment stakeholders have a negative view of the current spatial allocation of marine resource rights due to the perceived government prioritization of rights to indigenous groups [Org-Turf-Extr-Interview 5] or nonlocal organizations [Org-Turf-SSA-Interview 9], with fishers suggesting that the government prioritization of salmon and SSA rights over fishing rights is problematic [Org-Extr-Interview 12]. Government stakeholders report that most spatial assignments in the region have already been made [Gov-Interview 18], and nongovernment stakeholders state that the maritime authority's original space allocation left minimal distances between locations, which reduces the opportunity for new spatial assignments [Org-Turf-SSA-Interview 10]. That lack of unassigned space draws attention to opportunities to increase the use of space within existing TURFs for SSA [Gov-Interview 18, GovInterview 17 ] and conduct an Environmental Impact Statement [Gov-Interview 7]. 
With $40 \%$ of the space in TURFs available for SSA and government calls for more resourcebased activities such as SSA within existing TURFs [Gov-Interview 18], questions arise as to current perspectives and experiences of the conflict between uses and between users within a particular geographic location managed as a TURF. With current spatial marine resource rights, however, stakeholders report little such conflict. For example, a mussel-producing organization states that the area of their TURF is large enough that no spatial conflict among the group's many producers has occurred [Org-Turf-SSAInterview 9]. Similarly, women's organizations producing algae through a marine concession face no issues with sharing resources with other users and rights holders in the area [Org-womanInterview 6]. In the case of multiple uses within one geographic location, respondents describe agreements to prevent productivity interruptions for one activity due to another activity, such as rules to protect seaweed production from mussel extractors operating in the same TURF [Org-woman-Interview 6]. In fact, respondents reported two reasons to promote multiple marine activities in one location. First, having more users in one location acts as a deterrent to illegal activities and extraction within the location [Org-Turf-SSA-Interview 9]. Second, some biological systems can prove more productive when two resources are both managed, such as producing both seaweed and loco in the same location [Org-Turf-SSA-Interview 3]. In contrast, some respondents expressed concerns about the compatibility of some species in the same area [Org-Turf-Extr-Interview 1].

\section{Externalities}

In addition to considering the impact on multiple resource uses and users in one location, spatial management requires an assessment of the negative and positive impact of resource use in one location on resource use in other locations, i.e., negative and positive externalities. In particular, stakeholders depict generally acceptable relationships with salmon centers [Org-Turf-SSA-Interview 16, Org-Turf-SSA-Interview 13], but both negative and positive externalities are associated with proximity to salmon farms. Negative externalities include the spread of chemicals and other aspects of salmon farming that reduce productivity elsewhere [OrgTurf-Extr-Interview 15, Org-Extr-Interview 14, Org-Turf-SSA-Interview 16, Org-woman-Interview 6], salmon escaping from farms and reducing productivity nearby [Org-Turf-SSA-Interview 16], and the salmon industry invading the "fishing grounds" [Org-Extr-Interview 12]. Positive externalities from nearby salmon farms, however, include agreements between salmon producers and other marine resource users through which salmon producers provide waste that is recycled and used by neighbors [Org-Turf-SSA-Interview 13] and pay for reports [Org-Turf-SSA-Interview 16], in addition to the presence of guards to protect salmon farms, leading to the protection of nearby productive efforts. More broadly than salmon externalities, respondents report negative externalities such as conflict between neighboring users [Aqua-farmers-Interview 11] and a reduction in productivity due to high extraction levels in nearby locations [Aqua-farmers-Interview 11].

\section{Illegal extraction as an SSA risk}

Stakeholders perceive illegal extraction of resources in the areas where legal user rights have been assigned (TURFs, aquaculture concessions, special permits for mussel seed collection) as an important issue [Org-Turf-SSA-Interview 3]. Therefore, in general, monitoring is perceived as a necessary activity by most stakeholders. The

\footnotetext{
${ }_{10}$ This program, launched during 2014, has targeted TURFs located in the Los Lagos region. The program is intended to help local organizations holding TURFs rights to design, implement, and operate monitoring systems to reduce poaching in their areas (Chávez et al., 2018).
} 
only producers who do not consider the monitoring activity to be important are organizations without legal user rights [Org-Extr-Interview 12]. Illegal extraction might even induce producers to form an organization (trade union) to increase their capacity to protect the activity from illegal extraction [Org-Turf-SSA-Interview 10].

Regional authorities have identified areas where this illegal activity is more frequent and have invested in surveillance equipment (speed boats, radars, radio communications) [Gov-Interview $8] . .^{10}$ However, the capacity of public authorities to enforce these legal rights is perceived as limited by stakeholders, who have organized their own monitoring activities to complement those of the authorities, such as surveillance shifts in their production areas. They also obtain resources from the government to buy surveillance equipment, and they coordinate with the maritime authority when they detect illegal activity [Gov-Interview 10]. Nevertheless, the authorities state that some organizations do not report illegal extractions [Gov-Interview 8]. While private stakeholders are specifically interested in enforcing the exclusivity of their user rights, public authorities' enforcement covers a wide set of regulations beyond theft, such as safety at sea and harvested amounts [Org-Extr-Interview 12 and Gov-Interview 17].

Whether illegal extraction occurs depends on the value of the cultured resource, the location of the area, and community traditions. In the case of algae, the low value of the output seems to make illegal activity unattractive, so algae producers do not suffer from theft [Org-women-Interview 6]. Proximity to a salmon farm with its own surveillance system can also prevent theft [Org-
Turf-SSA-Interview 13]. Organizations without legal user rights report forms of informal user rights that communities recognize, especially if they have been operating for a long time and they respect the other users and their rights [Org-ExtrInterview 14]. All types of private stakeholders state that people who extract illegally are outsiders who do not belong to the organization, although they acknowledge the possibility that some community members might participate in the illegal activity [Org-Turf-SSA-Interview 3, Org-Turf-SSA-Interview 9, and Org-Turf-SSAInterview 10].

$\underline{\text { Restrictions arising from market structure and }}$ $\underline{\text { access }}$

Market structure and market access influence stakeholders' decisions to engage in SSA. First, two marine products have noncompetitive market structures. Only one seaweed buyer, Agarophyton chilensis, is reported to operate in the region, which limits options for individual and group seaweed producers [Org-women-Interview 6, OrgTurf-Extr-Interview 15, Org-Extr-Interview 14]. ${ }^{11}$ This situation is further complicated by a lack of local information about market prices [Org-ExtrInterview 14]. In contrast, one local organization collects mussel seeds and then operates as nearly the only seller of mussel seeds to local mussel growers, providing $90 \%$ of mussel seeds to local growers [Org-Turf-SSA-Interview 13].

Second, with marine products generated by both individuals and organizations, the current setting reflects a wide range of approaches to access markets, including a range of intermediary and contract types [Org-Turf-SSA-Interview 10]. Most products reach national or international markets

\footnotetext{
${ }^{11}$ The exact number of buyers (processors or intermediaries) at the time of the interviews is unknown. The information provided in the interviews could be due to the most recent experience of trading activity in the specific area. The key point here is that respondents are indicating that sellers must negotiate with a low number of buyers, which opens the possibility of market power.
} 
through the use of middlemen [Aqua-farmersInterview 11]. Some organizations operate models of individual production followed by organizations pursuing and defining contracts with buyers and intermediaries [Org-Turf-SSA-Interview 9, OrgTurf-SSA-Interview 13]. In some cases, buyers go directly to resource producers [Org-Turf-SSAInterview 10, Org-Turf-SSA-Interview 16], while in other cases, such as seaweed and fish sales, individual producers market their own output [Org-Turf-SSA-Interview 10, Org-Extr-Interview 14]. Fishers use a wide range of styles to sell their products [Org-Turf-SSA-Interview 10]. As is common in many low-income country agricultural settings, some contracts include financial support during the extraction and production season as part of the guaranteed sales agreement [Org-TurfSSA-Interview 13].

Third, stakeholders report several types of obstacles-especially supply chain access and market requirements - to marketing marine products that may influence their willingness or ability to increase their production of such resources. First, many stakeholders describe a lack of options and contacts with middlemen and other buyers that will enable them to access national and international markets [Org-TurfExtr-Interview 15, Org-Turf-SSA-Interview 13, Aqua-farmers-Interview 11]. The difficulty of establishing such connections generates a disadvantage in contract negotiations, such as a lack of information about prices [Org-Extr-Interview 14]. In addition, uncertainty and variability in production have created contract issues that lead to low prices [Aqua-farmers-Interview 11]. Second, stakeholders must contend with both quality standards and health and environmental standards that affect their ability to sell to national and international markets [Org-TurfSSA-Interview 13, Aqua-farmers-Interview 11]. Seaweed producers report a failure to meet the quality standards necessary to access international markets [Org-women-Interview 6]. Similarly, mussel and oyster producers face minimum size requirements for market access
[Aqua-farmers-Interview 11, Aqua-farmersInterview 4]. Without clear regulations and producer knowledge, marine resource product producers also face concerns about meeting environmental and health requirements in the production and sale of their products [Aquafarmers-Interview 11, Aqua-farmers-Interview 4, Org-Turf-SSA-Interview 13].

\section{Discussion}

Based on the results of the qualitative analysis of interviews, in this section, we discuss how public policies to promote SSA in Chile could address the concerns and restrictions encountered by potential SSA adopters.

\section{Key findings}

The qualitative results reveal several key considerations for policy. First, our qualitative results demonstrate that stakeholders see SSA as a source of additional income that complements other activities and that the adoption process is gradual rather than a complete and one-time shift in labor allocation to SSA. Second, the qualitative results show that younger people and women are most inclined to adopt SSA activities and that fishers perceive most SSA as requiring too large a lifestyle shift. Third, biogeographic diversity generates heterogeneity in the local profitability of different types of SSA. Finally, stakeholders face significant barriers to engaging in SSA, including production knowledge gaps specific to their region, upfront cost constraints, market access issues, and uncertainties concerning the legal setting for SSA.

Targeting policy to facilitate the transition from other activities to aquaculture

Policy success is determined by how people respond to a policy. Here, we examine the results 
through the lens of our conceptual model, which describes how people make decisions about adopting new income-generating activities, and discuss what those findings imply for targeting policy to promote SSA adoption. As above, households seek to maximize their expected utility from allocating time and funding to different incomegenerating activities, subject to constraints. Here, expected utility from adopting SSA is a function of additional income generated and preferences across lifestyles, with constraints on the current setting, available time and capital, information set, and opportunity set.

Expected additional income from these activities forms a central part of stakeholder decisions to adopt SSA. First, our results demonstrate, however, that many stakeholders are constrained by their lack of information about different productive processes and about the profitability of these activities in their setting. In addition, stakeholders and other research find large geographic diversity in the ability to employ SSA and in each type of SSA's profitability, which informs the set of opportunities available to particular households. These findings suggest that expanding SSA extension activities and offering extensions that are specific to particular settings would reduce this constraint on SSA adoption. Second, stakeholders face market access and market structure issues that reduce their expected income from SSA, in addition to uncertainty about health and production restrictions. Extension activities to offer information and improve market access, combined with clear regulations about SSA market rules, would enable stakeholders to more accurately foresee expected profits from engaging in SSA. Third, even households that foresee long-run profits from undertaking SSA can face constraints to adoption due to the upfront costs involved in these new activities. Improvements in the regulatory setting around SSA and other policies that enable households to receive credit to invest in SSA would increase SSA uptake among households that face capital constraints. Fourth, because illegal harvesting and the costs of moni- toring to deter that theft reduce expected income from SSA, policies that strengthen coenforcement to protect user rights, especially policies that target high poaching areas, would increase SSA adoption. Such efforts include complementing monitoring efforts, subsidizing monitoring technologies, and enhancing coordination between producers holding marine user rights and authorities (Chávez et al., 2021), in addition to improving the judicial system to increase the deterrence effect of monitoring efforts (Chávez et al., 2021).

The conceptual model of SSA adoption decisions also considers aspects of the variability of income, risk, and other preferences. In addition to its impact on the expected income, uncertainties related to production, marketing processes and the legal structure deter adoption simply because uncertainty is undesirable, with those uncertainties leading to similar policy responses as described above. Perhaps reflecting stakeholder caution in the face of such uncertainty in addition to upfront costs, our results demonstrate that households rarely envision a complete shift to SSA. Instead, they incorporate SSA as an additional income-generating activity into their current set of activities and then expand that activity slowly over time, which generates a more diverse set of activities in the long run. Governments should not expect sudden and drastic upswings in SSA and could devise policies that help households identify activities that will complement their existing activity set. In addition, our results indicate diversity across stakeholder types in terms of preferences for adopting SSA. Policies that target young people and women would take advantage of these stakeholders' relative inclination toward SSA. Similarly, fishers have strong preferences for a resource extraction lifestyle and are less likely to adopt SSA than other people, which implies that standard policies will generate a low response from fishers and that policies targeting fishers may thus need to reflect lifestyle issues more so than income, knowledge, and capital constraints. 


\section{Spatial limitations on SSA expansion}

The availability of space in which to conduct SSA also factors into households' decisions to adopt SSA through the set of possible opportunities. Because productivity varies across biogeographic locations (Buschmann et al., 1995; Bagnara \& Maltrain, 2008) and because currently existing marine resource rights often include specific locations (Albers et al., 2021), the current spatial characteristics of the seascape's rights and users form an initial condition that informs and constrains future patterns of marine resource use. Beyond a constraint on households, government officials report that the area available for future SSA expansion lies primarily in the unexploited area in the TURFs because most other areas have already been assigned. However, according to our interviews, the unused area in TURFs is not allocated to SSA because it lacks the natural and productivity conditions for profitable SSA. Therefore, any policy to expand SSA must address whether space permits such growth. In November 2019, a new law (Law 21.183) that allows relocating aquaculture concessions for SSA and provides more juridical certainty for mussel seed collectors was enacted. Relocation allows merging adjacent areas and resolving cartographic inaccuracies, which is expected to increase the total area that can be used for SSA. This law was approved more than one year after our interviews were conducted, so stakeholders probably did not consider this possibility in their responses. However, the real effect that the relocation opportunities that this law opens will have on the area expansion for SSA remains to be seen. Moreover, as mentioned above, the use of area for aquaculture purposes depends on not only space availability but also natural and productive conditions for profitable activity. Furthermore, our results find potential conflicts and both positive and negative externalities across and within spatial locations with various productive activities. The current spatial distribution of user rights creates an initial condition that constrains options for the expansion of SSA that future policy must address.

\section{Does the proposed policy address constraints on SSA adoption and expansion?}

Our results suggest that creating a well-functioning legal framework that contains rules specific to small-scale aquaculture and with a clear definition of the available space for SSA is important for reducing uncertainty and spatial conflicts and therefore increasing SSA adoption. The new Chilean regulation to promote SSA emphasizes the importance of credit access for potential SSA stakeholders, which our results indicate is an important constraint (PNA, 2003; Subsecretaría de Pesca, 2019b). In addition, the new law 21,183 can give juridical certainty to mussel seed collectors, which should contribute to giving more stability to the mussel farming sector. Nevertheless, the new policy should also consider restrictions in terms of the payment capacity of the SSA business, such as relating the environmental and sanitary requirements to the size of the farm and posing patenting and reporting costs in line with the business's financial capabilities. In addition, the legal characteristics of marine user rights should be revisited to increase the certainty of rights holders. Furthermore, by focusing on individual producers, the proposal loses sight of the aggregate or marinescape production of marine outputs as well as the aggregate environmental or sanitary effects generated by many agglomerated small producers or patterns of resource use. This narrow focus can potentially generate additional negative externalities in some locations that can arise from the agglomeration of farms, as the bivalve mollusk aquaculture literature has reported (Whitmarsh \& Palmieri, 2008; Mongruel \& Thébaud, 2006;

12 In addition, other aspects of the proposal that can be discussed are whether the proposal encourages small producers to develop their business and become independent of the preferential treatment or if onshore closed aquaculture is a real option for small producers, given the costs associated with this type of business 
Le Grel \& Le Bihan, 2009; Poirine, 2003). Finally, the proposal does not promote polyculture aquaculture or the exploration of new species. ${ }^{12}$

\section{Conclusion}

We presented the results of qualitative analysis of key informant semistructured interviews with stakeholders about their views on the potential opportunities and obstacles of promoting SSA as an additional income-generating activity for coastal communities in the Los Lagos RegionChile. The identification of the main challenges and opportunities informs the next steps in public policy to promote SSA in the country. Overall, our analysis demonstrates significant potential for expanding SSA in this region and the related increase in economic development and household income. The existing limitations for expanding aquaculture through new concessions imply that surface expansion should result primarily from incorporating unused areas in existing TURFs. Nevertheless, well-defined policies complemented by extension services that are location- and species-specific and by extension services that address market requirements and market access obstacles are necessary to encourage most stakeholders to expand or adopt SSA. Moreover, to increase the effectiveness of these policies, it is recommended that they be designed considering stakeholder-specific characteristics.

\section{Acknowledgments}

We gratefully acknowledge financial support for this research from the Swedish International Development Cooperation Agency (Sida) through the Environment for Development (EfD) Initiative at the University of Gothenburg under project MS-368 "Small-scale aquaculture as a livelihood alternative with marine conservation benefits in coastal communities in Chile". Baquedano, Chávez, and Dresdner also gratefully acknowledge additional partial funding for this research provided by INCAR through ANID/ FONDAP/15110027.

\section{Resumen}

H.J. Albers, M. Baquedano, C. Chávez, J. Dresdner, y K. Yubini. 2021. Oportunidades y desafíos para la acuicultura de pequeña escala: La perspectiva de las partes interesadas en la Región de Los Lagos-Chile. Int. J. Agric. Nat. Resour. 259-287. Identificamos y exploramos las potenciales oportunidades y desafíos para promover y expandir la acuicultura a pequeña escala (APE) como una actividad generadora de ingresos adicional para las comunidades costeras en el sur de Chile. Basados en un modelo conceptual sobre decisiones de adopción de APE, llevamos a cabo entrevistas de informantes clave en el campo con actores de la región de Los Lagos y en la capital regional Puerto Montt. Desarrollamos un análisis cualitativo de las entrevistas para identificar las percepciones sobre oportunidades actuales para implementar APE de potenciales usuarios. La interpretación de los resultados del análisis de contenido, a través del lente de las decisiones económicas del modelo conceptual, nos permite identificar que un débil monitoreo y fiscalización, dificultades en adaptarse a nuevos trabajos, limitaciones de la planificación espacial reciente, restricciones al acceso a derechos de uso marinos, e insuficiente desarrollo en los mercados para productos marinos, se encuentran entre los principales obstáculos para la adopción de APE. Los actores ven la APE como una oportunidad para ampliar las actividades productivas marinas ante el continuo declive de la pesca salvaje. La adopción de la APE se percibe como un proceso de transición gradual que requiere capital cultural y conocimientos, dada la falta de familiaridad con la gestión y los aspectos legales y económicos de la acuicultura. En contraste con las preocupaciones de los potenciales adoptantes de la APE, las partes interesadas del gobierno 
destacan la preocupación por la falta de definiciones para la APE de normas y reglamentos. Discutimos cómo las políticas públicas para promover la APE en Chile podrían dirigirse a las principales preocupaciones de los potenciales adoptantes de la APE

Palabras clave: Actividades generadoras de ingreso, acuicultura, análisis cualitativo y pesquerías.

\section{References}

Ahmed, M., Mylene H., \&Lorica, M.H. (2002). Improving developing country food security through aquaculture development-Lessons from Asia. Food Policy, 27(2), 125-141.

Albers, J., Chávez, C., Dresdner, J., \& Leiva, M. (2021). "Prospects for small-scale aquaculture in Chile: User Rights and Locations", Marine Resource Economics, 36(4), 389-410. https://doi. org/10.1086/715548.

Aspers, P., \& Corte, U. (2019). What is qualitative in qualitative research. Qualitative sociology, 42(2), 139-160. https://doi.org/10.1007/s11133019-9413-7

Bagnara, M., \& Maltrain, G. (2008). Descripción del sector mitilicultor en la región de Los Lagos, Chile: evolución y proyecciones. In A. Lovatelli, A. Farías, E \& Uriarte, I (eds). Estado actual del cultivo y manejo de moluscos bivalvos y su proyección futura: factores que afectan su sustentabilidad en América Latina. Taller Técnico Regional de la FAO. 20-24 de agosto de 2007, Puerto Montt, Chile. FAO Actas de Pesca y Acuicultura, Roma, FAO 12.,189-198.

Buschmann, A.H., Westermeier, R., \& Retamales, C.A. (1995). "Cultivation of Gracilaria on the sea-bottom in southern Chile: a review." Journal of Applied Phycology 7 (3), 291-301. https://doi. org/10.1007/BF00004003

Chávez, C., Murphy J., \& Stranlund J. (2018). "Managing and Defending the Commons: Experimental Evidence from TURFs in Chile", Journal of Environmental Economics and Management 91: $229-246$.

Chávez, C., Murphy, J., \& Stranlund, J. (2021). “CoEnforcement of Common Pool Resources to De- ter Encroachment. Evidence from a Field Experiment in Chile", under review at Environmental and Resource Economics.

CORFO. (2016). "Hoja de Ruta Programa Estratégico Nacional-Acuicultura. Resumen Ejecutivo," Estudio ejecutado por UNTEC y financiado por la Corporación de Fomento de la Producción, Ministerio de Economía, Fomento y Turismo, 26. www.corfo.cl

Diedrich, A., Blythe, J., Petersen, E., Euriga, E., Fatchiya., A., Shimada, T., \& Jones, C. (2019). Socio-economic drivers of adoption of smallscale aquaculture in Indonesia. Sustainability 11 (6), 1543. https://doi.org/10.3390/su11061543

FIPA 2004-26 "Diagnóstico de la acuicultura de pequeña escala en Chile". Fondo de Investigación Pesquera y de Acuicultura, Subsecretaría de Pesca y Acuicultura, Chile. https://www.subpesca.cl/fipa/613/w3-article-89063.html

FIPA 2005-15 "Evaluación ambiental y sanitaria de la acuicultura a pequeña escala" Fondo de Investigación Pesquera y de Acuicultura, Subsecretaría de Pesca y Acuicultura, Chile. https://www. subpesca.cl/fipa/613/w3-article-89097.html

FIPA 2007-48 "Diagnóstico y evaluación de las competencias y gestión de las organizaciones de pescadores artesanales y acuicultores de pequeña escala". Fondo de Investigación Pesquera y de Acuicultura, Subsecretaría de Pesca y Acuicultura, Chile. https://www.subpesca.cl/fipa/613/ articles-89213_informe_final.pdf

FIPA 2015-02 "Diseño y valoración de modelos de cultivos para la acuicultura de pequeña escala". Fondo de Investigación Pesquera y de Acuicultura, Subsecretaría de Pesca y Acuicultura, Chile. https://www.subpesca.cl/fipa/613/w3-article-92059.html 
FIPA 2017-16 “Adecuación de la normativa ambiental y sanitaria a proyectos de acuicultura a pequeña escala (APE)". Fondo de Investigación Pesquera y de Acuicultura, Subsecretaría de Pesca y Acuicultura, Chile. https://www.subpesca. cl/fipa/613/w3-article-97679.html

Flick, U (2006) An introduction to qualitative research, SAGE publications, Third Edition.

Food and Agricultural Organization (FAO) of the United Nations. (2018). https://www.fao.org/3/ cb1213t/cb1213t.pdf

Food and Agricultural Organization (FAO) of the United Nations.(2017). http://www.fao.org/fishery/static/Yearbook/YB2017_USBcard/navigation/index_intro_s.htm

Garlock, T., Asche, F., Anderson, J.L., Bjørndal, T., Kumar, G., Lorenzen, K., Ropicki, A., Smith, M.D., \& Tveterås, R. (2020). A Global Blue Revolution: Aquaculture Growth across Regions, Species, and Countries. Reviews in Fisheries Science and Aquaculture. 28(1), 107-116 https://doi.org/10.1080/23308249.20 19.1678111

Glasser, B.G., \& Strauss, A.L. (2017). Discovery of grounded theory: Strategies for qualitative research. Routledge.

GLFA, (2019). "General Law of Fishing and Aquaculture". Updated text that includes modification of law $\mathrm{N}^{\circ} 21.287$, Chilean Government, http:// www.subpesca.cl/portal/615/w3-article-88020. html

Kaliba, A., Ngugi, C.C., Mackambo, J.M., Osewe, K.O., Senkondo, E., Mnembuka, B.V., \& Amisah, S. (2007). Potential effect of aquaculture promotion on poverty reduction in Sub-Saharan Africa. Aquaculture International 15(6) 445-459. https://doi.org/10.1007/s10499-007-9110-5

Le Grel, L., \& Le Bihan, V. (2009). Oyster farming and externalities: the experience of the Bay of Bourgneuf. Aquaculture Economics \& Management, 13(2), 112-123. https://doi. org/10.1080/13657300902881690

Mongruel, R., \& Thébaud, O. (2006). Externalities, institutions and the location choices of shellfish producers: the case of blue mussel farming in the Mont-Saint-Michel bay (France). Aquaculture Economics \& Management, 10(3), 163-181. https://doi. org/10.1080/13657300600985173

E-Jahan, K.M., Ahmed, M., \& Belton, B. (2010). The impacts of aquaculture development on food security:Lessons from Bangladesh. Aquaculture Research, 41(4), 481-495. https://doi. org/10.1111/j.1365-2109.2009.02337.x

Patton, M.Q. (2002). Qualitative Research and Evaluation Method. Third edition. Sage.

Pierpaoli, E, Carli, G., Pignatti, E., \& Canavari, M. (2013). Drivers of precision agriculture technologies adoption: A literature review. Procedia Technology, 8:61-69. https://doi.org/10.1016/j. protcy.2013.11.010

Poirine, B. (2003). Managing the commons: an economic approach to pearl industry regulation. Aquaculture Economics \& Management, 7(3-4), 179-193. https://doi. org/10.1080/13657300309380339

PNA, (2003). National Aquaculture Policy. Subsecretaría de Pesca y Acuicultura, Chilean Government. https://www.subpesca.cl/portal/616/w3article-60019.html

Salazar, C., Jaime, M., Figueroa, Y., \& Fuentes, R. (2018). Innovation in small-scale aquaculture in Chile. Aquaculture Economics \& Management, (22)2, 151-167. https://doi.org/10.1080/136573 05.2017.1409293

Slater, M.J., Mgaya, Y.D., Mill, A.C., S.P., Rushton, \& Stead, S.M. (2013). Effect of social and economic drivers on choosing aquaculture as a coastal livelihood. Ocean \& Coastal Management. 73:22-30. https://doi.org/10.1016/j.ocecoaman.2012.12.002

Strauss, A., \& Corbin, J.M (1997) Grounded theory in practice. Sage.

Subsecretaría de Pesca y Acuicultura. (2019a). "Estado de Situación de las Principales Pesquerías Chilenas 2018," Departamento de Pesquerías, Subdivisión de Administración Pesquera, Subsecretaría de Pesca y Acuicultura, Gobierno de Chile 1-102. http://www.subpesca.cl/portal/618/ articles-103742_recurso_1.pdf 
Subsecretaría de Pesca y Acuicultura. (2019b). "Propuesta de Reglamento para la Acuicultura a Pequeña Escala", Informe Técnico (D.AC.) (November, 12), 884,1-44.

Teddlie, C., \& Yu, F. (2007). Mixed methods sampling: A typology with examples. Journal of mixed methods research, 1(1), 77-100. https:// doi.org/10.1177/1558689806292430
Whitmarsh D., \& Palmieri, M.G. (2008). Aquaculture in the Coastal Zone: Pressures, Interactions and Externalities. In: Holmer M., Black K., Duarte C.M., Marbà N., Karakassis I. (eds) Aquaculture in the Ecosystem. Springer, Dordrecht. https://doi.org/10.1007/978-1-40206810-2 8 . 


\section{Appendix}

APPENDIX: Semistructured interview questionnaire by stakeholder category

\begin{tabular}{|c|c|c|c|c|}
\hline Stakeholder & SAA & Enforcement & Organization/fishers settings & Others \\
\hline $\begin{array}{l}\text { Central } \\
\text { Government }\end{array}$ & $\begin{array}{l}\text { - Describe your main } \\
\text { experiences with SSA: } \\
\text { locations, species, } \\
\text { organization forms, use of } \\
\text { subsidies or other incentives, } \\
\text { and results. } \\
\text { - What are the primary goals } \\
\text { of SSA development? } \\
\text { - What type of policy } \\
\text { instruments are proposed to } \\
\text { promote SSA? What are the } \\
\text { expected outcomes? } \\
\text { - What type of people will } \\
\text { be targeted with SSA (e.g., } \\
\text { TURF members, union } \\
\text { members, artisanal fishers } \\
\text { not in groups, nonfishers, } \\
\text { women from fishing or } \\
\text { nonfishing households)? } \\
\text { - What benefits do you } \\
\text { expect from a broader use } \\
\text { of SSA, as opposed to other } \\
\text { livelihood activities that } \\
\text { might not rely on marine } \\
\text { resources? }\end{array}$ & $\begin{array}{l}\text { - What is the } \\
\text { government's role in } \\
\text { protecting property rights } \\
\text { such as in TURFs or } \\
\text { for particular species? } \\
\text { Problems? Experiences? } \\
\text { Conflict? } \\
\text { - What are your views } \\
\text { on enforcement issues } \\
\text { facing union/coops/TURF } \\
\text { organizations? Are harsher } \\
\text { legal sanctions being } \\
\text { considered? Are increased } \\
\text { water-space rights being } \\
\text { considered? }\end{array}$ & & $\begin{array}{l}\text { - What is the government's } \\
\text { role in protecting property } \\
\text { rights such as in TURFs } \\
\text { or for particular species? } \\
\text { Problems? Experiences? } \\
\text { Conflict? } \\
\text { - What are your views } \\
\text { on enforcement issues } \\
\text { facing union/coops/TURF } \\
\text { organizations? Are harsher } \\
\text { legal sanctions being } \\
\text { considered? What about } \\
\text { increased water-space } \\
\text { rights? }\end{array}$ \\
\hline
\end{tabular}




\begin{tabular}{|c|c|c|c|c|}
\hline $\begin{array}{l}\text { All } \\
\text { organizations }\end{array}$ & $\begin{array}{l}\text { - What is your view toward } \\
\text { SSA? Do you have plans to } \\
\text { pursue SSA in the coming } \\
\text { years? } \\
\text { - What are the benefits } \\
\text { and limitations of SSA } \\
\text { (e.g., technical, financial, } \\
\text { knowledge)? } \\
\text { - For what purposes would } \\
\text { government subsidies or } \\
\text { programs geared toward SSA } \\
\text { be most useful? }\end{array}$ & $\begin{array}{l}\text { • Has enforcement been } \\
\text { an issue? } \\
\text { • Which do you think } \\
\text { is more important: } \\
\text { enforcement of } \\
\text { organization rules within } \\
\text { the membership, or } \\
\text { enforcement against } \\
\text { actions taken by } \\
\text { those outside of the } \\
\text { organization? } \\
\text { - What are your ways } \\
\text { (including sanctions) of } \\
\text { preventing members from } \\
\text { shirking responsibilities or } \\
\text { overharvesting? What are } \\
\text { your ways of preventing } \\
\text { nonmembers (both from } \\
\text { within and outside of } \\
\text { the community) from } \\
\text { poaching? Have you been } \\
\text { successful with either/ } \\
\text { both? } \\
\text { - For what purposes } \\
\text { would government } \\
\text { subsidies or programs } \\
\text { oriented toward } \\
\text { enforcement be most } \\
\text { useful? }\end{array}$ & $\begin{array}{l}\text { - How many members are in } \\
\text { your organization, and how } \\
\text { do you determine the optimal } \\
\text { number of members? } \\
\text { - How does your organization } \\
\text { allocate both rights (e.g., } \\
\text { amount of harvest) and } \\
\text { responsibilities (e.g., } \\
\text { enforcement, paperwork) } \\
\text { across members and across } \\
\text { time? } \\
\text { - In general, how is labor } \\
\text { allocation among members } \\
\text { determined? } \\
\text { - How are benefits/revenues } \\
\text { allocated among the members } \\
\text { in your organization? How } \\
\text { does this allocation differ over } \\
\text { the course of a year? } \\
\text { - How do you determine } \\
\text { extractive activities and } \\
\text { locations? How do those differ } \\
\text { over the course of a year? } \\
\text { - If your organization harvests } \\
\text { more than one resource, } \\
\text { how are those resources } \\
\text { managed differently? Please } \\
\text { mention both the timing of } \\
\text { harvests and the member } \\
\text { responsibilities and rules } \\
\text { related to different resources. } \\
\text { Do the responsibilities and } \\
\text { rules differ by member? } \\
\text { - How much participation is } \\
\text { there by women, and how do } \\
\text { their roles compare to those } \\
\text { of men? }\end{array}$ & $\begin{array}{l}\text { - Do you have plans to } \\
\text { incorporate additional } \\
\text { (perhaps nonextractive) } \\
\text { activities in the coming } \\
\text { years? If so, what are } \\
\text { the expected reactions or } \\
\text { outcomes to those additional } \\
\text { planned activities? }\end{array}$ \\
\hline $\begin{array}{l}\text { Organization } \\
\text { with TURFs }\end{array}$ & $\begin{array}{l}\text { - Why have you chosen/ } \\
\text { not chosen to engage in SSA } \\
\text { within your TURF? } \\
\text { - What rights or incentives } \\
\text { would encourage you to } \\
\text { engage in (more) SSA? } \\
\text { To engage in (more) SSA, } \\
\text { would you: increase your } \\
\text { membership, undertake } \\
\text { those activities during slack } \\
\text { periods for benthic resources, } \\
\text { or allocate time away from } \\
\text { benthic resources? }\end{array}$ & $\begin{array}{l}\text { - How do you undertake } \\
\text { enforcement against } \\
\text { nonmembers? Is that } \\
\text { activity conducted by } \\
\text { specific people or by } \\
\text { everyone? Does that } \\
\text { activity occur while } \\
\text { those people perform } \\
\text { other activities, or is it } \\
\text { enforcement-specific? } \\
\text { - How would you } \\
\text { characterize the amount } \\
\text { of time and effort invested } \\
\text { in enforcement versus } \\
\text { other activities, such as } \\
\text { harvesting? } \\
\text { - When was the last } \\
\text { time your group caught } \\
\text { nonmembers extracting? } \\
\text { What happened? }\end{array}$ & & $\begin{array}{l}\text { - If your organization } \\
\text { has rights to nonbenthic } \\
\text { resources, where and when } \\
\text { do members fish for those } \\
\text { nonbenthic resources? How } \\
\text { do you manage different } \\
\text { rules and responsibilities } \\
\text { for each species/resource } \\
\text { or an overarching set of } \\
\text { allocations of member time? } \\
\text { - What are some ways that } \\
\text { spatial rights have led to the } \\
\text { development of profitable, } \\
\text { nonextractive income- } \\
\text { generating activities? }\end{array}$ \\
\hline
\end{tabular}




\begin{tabular}{|c|c|}
\hline $\begin{array}{l}\text { Organization } \\
\text { without } \\
\text { TURFs }\end{array}$ & $\begin{array}{l}\text { - Have you considered } \\
\text { applying for a TURF? Why } \\
\text { or why not? } \\
\text { - Do you extract } \\
\text { (nonbenthic) resources } \\
\text { from areas where other } \\
\text { organizations have spatial } \\
\text { rights to benthic resources? } \\
\text { If so, has that led to any } \\
\text { conflicts? }\end{array}$ \\
\hline $\begin{array}{l}\text { Women only } \\
\text { organization }\end{array}$ & $\begin{array}{l}\text { - Why and how did this } \\
\text { women-only group arise? } \\
\text { - What do you do } \\
\text { differently than other } \\
\text { organizations? } \\
\text { - How has your } \\
\text { organization created new } \\
\text { opportunities or power for } \\
\text { women? }\end{array}$ \\
\hline
\end{tabular}




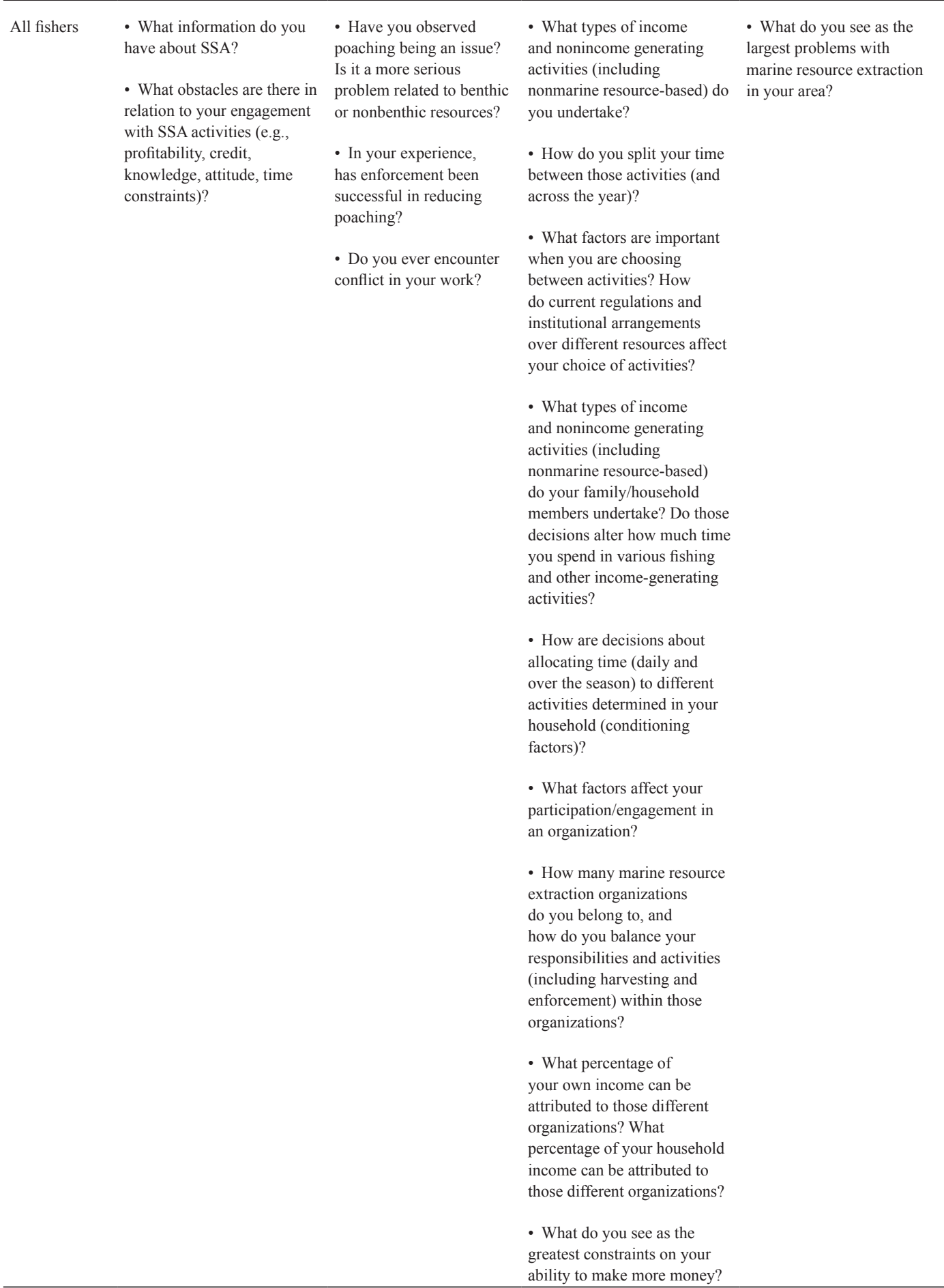




\begin{tabular}{|c|c|c|c|}
\hline $\begin{array}{l}\text { Fishers that are } \\
\text { members of } \\
\text { TURF-granted } \\
\text { organizations }\end{array}$ & $\begin{array}{l}\text { - What are the potential pros } \\
\text { and cons of SSA within your } \\
\text { TURF area? } \\
\text { - How would you expect } \\
\text { your organization, your } \\
\text { activities, and your income } \\
\text { to change if SSA were } \\
\text { established in your TURF } \\
\text { area? }\end{array}$ & $\begin{array}{l}\text { - Overall, has poaching } \\
\text { been an issue for your } \\
\text { organization? Is it a bigger } \\
\text { problem related to benthic } \\
\text { or nonbenthic resources? } \\
\text { Is it a larger problem } \\
\text { related to organization } \\
\text { members or nonmembers? } \\
\text { - What types of } \\
\text { enforcement activities } \\
\text { does your organization } \\
\text { engage in? Do you } \\
\text { participate in any/all of } \\
\text { these? } \\
\text { - What is your view } \\
\text { on how effective those } \\
\text { enforcement activities are? } \\
\text { - Does your organization } \\
\text { efficiently/fairly } \\
\text { assign enforcement } \\
\text { responsibilities? } \\
\text { - Which do you think } \\
\text { is more important: } \\
\text { enforcement of } \\
\text { organization rules } \\
\text { within the membership } \\
\text { or enforcement against } \\
\text { actions taken by } \\
\text { those outside of the } \\
\text { organization? }\end{array}$ & $\begin{array}{l}\text { - How much time do you } \\
\text { spend on the following: } \\
\text { - Harvesting benthic } \\
\text { resources through the } \\
\text { organization? } \\
\text { - Harvesting nonbenthic } \\
\text { resources through the } \\
\text { organization? } \\
\text { - Nonharvest activities for the } \\
\text { organization? } \\
\text { - Harvesting benthic } \\
\text { resources outside of the } \\
\text { organization? } \\
\text { - Harvesting nonbenthic } \\
\text { resources outside of the } \\
\text { organization? } \\
\text { - Nonharvest activities } \\
\text { outside of the organization? } \\
\text { - Do you undertake these } \\
\text { activities at the same time or } \\
\text { separately? }\end{array}$ \\
\hline
\end{tabular}


Fishers that are members of organizations that do not have TURFs
- Overall, has poaching been an issue for your organization? Is it a larger problem related to benthic or nonbenthic resources? Is it a larger problem related to organization members or nonmembers?

- What sort of enforcement activities does your organization engage in? Do you participate in any or al of those?

- What is your view on how effective those enforcement activities are?

- Does your organization efficiently/fairly assign enforcement responsibilities?

- Which do you think is more important: enforcement of organization rules within the membership or enforcement against actions taken by those outside of the organization?
- Fishers that are not members of organizations
- How often do you fish in an area where an organization has rights to the benthic resources? Has that created any problems/ conflict?

- How often do you fish in an area where an organization has rights to the nonbenthic resources? Has that created any problems/conflict?
- How much time do you spend on the following:

- Harvesting benthic resources through the organization?

- Harvesting nonbenthic resources through the organization?

- Nonharvest activities for the organization?

- Harvesting benthic resources outside of the organization?

\section{- Harvesting nonbenthic} resources outside of the organization?

- Nonharvest activities outside of the organization?

- Do you undertake these activities at the same time or separately?
- Do you wish that your organization had a TURF? Why or why not?

- How often do you fish in an area where you know that a different organization has rights to the benthic resources? Have conflicts arisen?
- How much time do you spend on the following:

- Harvesting benthic resources?

- Harvesting nonbenthic resources?

- Nonharvest activities?

- Do you undertake these activities at the same time or separately?
- What made you decide not to join an organization? Was it a voluntary or an involuntary decision?

- If voluntary, have you ever considered joining an organization?

- If involuntary, why were you not able to join?

- Have you been able to harvest enough resources to generate your desired level of income?

- Have you had to substitute marine resource-based activities with other nonmarine resource-based activities?

- Please comment on the mobility of your lifestyle. Are you more or less mobile now than before TURFs were established? 